\title{
NUTRIENT CONCENTRATIONS AND pH IN THE CISADANE ESTUARINE AND COASTAL WATERS
}

\author{
Muswerry Muchtar \\ Research Center for Oceanography, Indonesian Institute of Sciences \\ Jl. Pasir Putih 1, Ancol Timur, Jakarta - 11048, Indonesia \\ e-mail:mus@indo.net.id
}

\begin{abstract}
The study on the fluctuation of dissolved nutrient concentrations and acidity $(\mathrm{pH})$ in the Cisadane Estuary was carried out in May 2004 October 2004 and July 2005. Inorganic phosphate, nitrate and silicate of the surface water were analyzed, using Spectrophotometer and $\mathrm{pH}$ was measured with a $\mathrm{pH}$ meter. Generally the nutrient concentrations in the estuary were higher compared to those in the coastal and offshore areas. The concentrations were gradually becoming lower and lower toward the open sea. Their fluctuation depended not only on the environmental condition but also on the water volume from the land and the mangrove forest in that area.
\end{abstract}

Keywords: Nutrient, Acidity ( $\mathrm{pH})$, Cisadane Estuary, Coastal water, Java Sea

\section{INTRODUCTION}

Inorganic phosphate and nitrate are the primary nutrient used by phytoplankton for growing. Generally they are used at the same concentrations, but some scientists reported that the nitrogen concentrations used were higher than phosphate (Harvey, 1957). In the marine environment phosphate is released by microbial phosphates action on detritus material (Strickland and Solorzano, 1966; Ayyakanu and Chandramohan, 1970).

Cisadane Estuary is located in the western part of the Banten Province in the Sunda Strait. The estuary is influenced by its surrounding land activities, such as on tourism, human settlement, and establishment of factories. Battery and plastic factories, fish landing facility, houses, schools and markets and tourism transportation are found in the surrounding area of the Cisadane estuary. Anthropogenic activities are the major source of nutrients that are transported by the urban and agricultural runoff. These activities produce wastes that are discharged through the rivers into the estuary. Ninety percent of the inhabitants of this area are fishermen.
The harbor activities have been increasing through time which can be seen in the year to year increase of the number of tourists and fishermen boats. These activities have certainly affected the environmental conditions of the waters with potential grave impact to the chemical, physical and biological conditions of this estuary.

Cameron and Pritchard (1963) said that estuary is a semi enclosed waters, has free relation with the open sea and in this waters there occurs the mixing between the sea water and fresh water flowing from the land. The form and width of the estuary will change because of the erosion, sedimentation and the increase and decrease of sea water level (Dyer, 1973). According to Nybakken (1988) one thing that is specific in estuary is the salinity fluctuation, which depends on the season, tide and the water masses flowing into it. Of the topography, Cameron and Pritchard (1963) classified the estuary in tropical water as coastal plain estuary with the delta in front of it. The estuary of this type is called the shallow water estuary.

The studies on the oceanological conditions of estuaries in Indonesia are still limited. This paper describes the result of the study on the fluctuation 
of nutrient concentrations and acidity $(\mathrm{pH})$ of the Cisadane Estuary.

\section{MATERIALS AND METHODS}

The study was carried out in Cisadane estuary, western part of Banten Province. Two stations in estuary and 16 stations at the coastal and offshore areas were carried out using fishermen boat, in May 2004, October 2004 and July 2005 (Fig.1).

Water samples were collected using Nansen bottles at surface water and were kept in the polyethylene bottles for nutrient: phosphate, nitrate and silicate; $\mathrm{pH}$ were analyzed directly using $\mathrm{pH}$ meter. The water samples were filtered through a Millipore $0.45 \mu \mathrm{m}$ mesh size. Phosphate, nitrate and silicate were analyzed using spectrophotometer on the same day of sampling according to the methods described by Strickland and Parsons (1968). The nutrients concentrations were expressed in $\mu \mathrm{g}$-at $/ 1$.

\section{RESULT AND DISCUSSION}

\section{Phosphate}

The concentrations of phosphate in the estuary and in coastal areas are shown in Table 1 and 2. Figure 2 show the distribution of phosphate at surface waters, in front of the Cisadane river mouth, which is higher compared to the rest of the areas. Figure 3 and 4 show the distribution of phosphate concentrations at surface waters which decreases gradually from the river toward the coastal and offshore areas. In general the phosphate concentrations in the estuary were higher than those in the coastal and offshore areas. This was due to the supply of inorganic material from the land, from domestic waste and industrial effluent surrounding Cisadane River

Figure 5 shows the phosphate concentrations in the river in October 2004 were very high than those in May 2004 and July 2005. Figure 5 also show the mean concentrations of phosphate at coastal and offshore area in May 2004, October

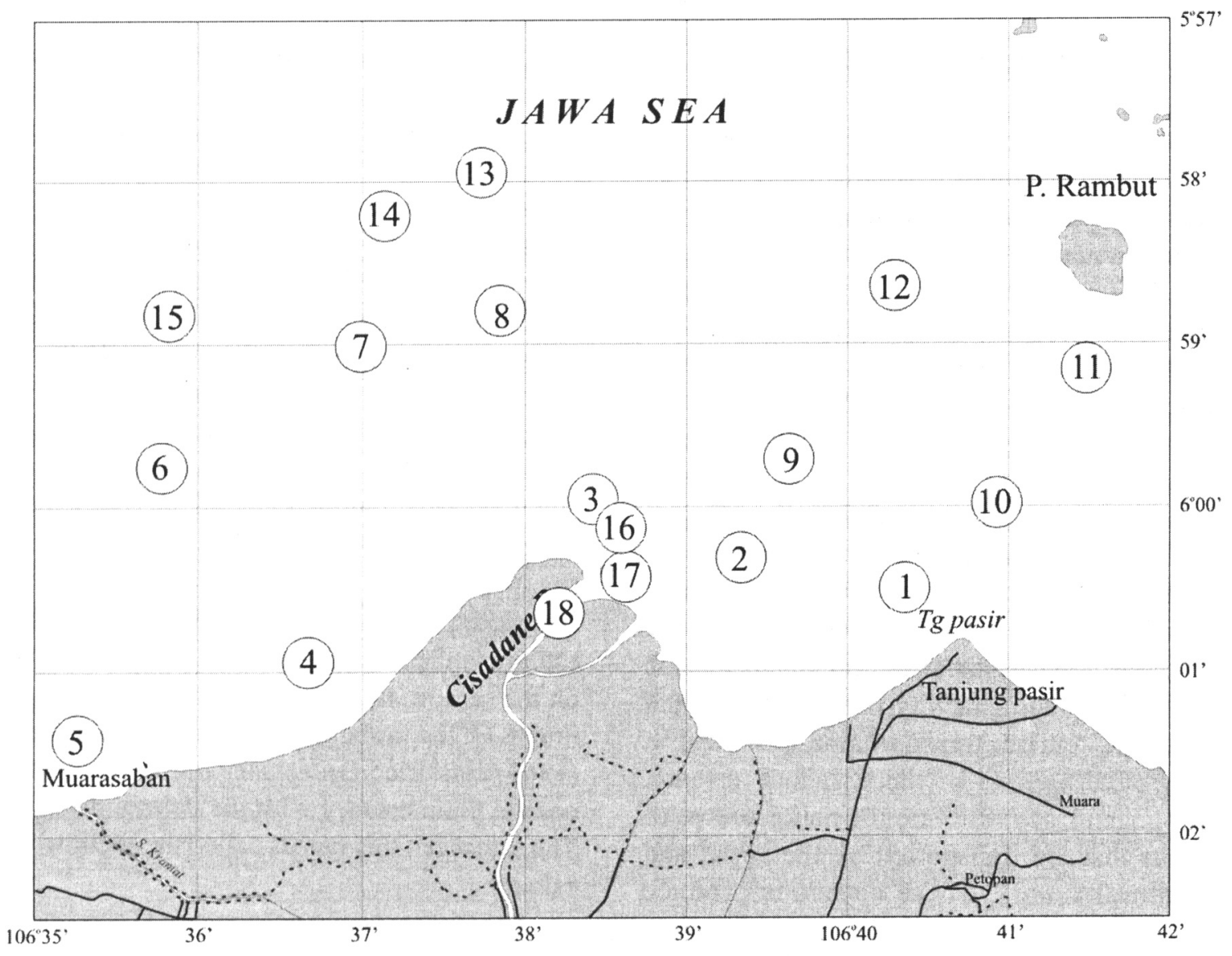

Figure 1. The sampling site in Cisadane Estuary, May 2004, October 2004 and July 2005. 
Table 1. Acidity $(\mathrm{pH})$ and nutrient concentrations in the coastal and offshore in the Cisadane in, May 2004, October 2004 and July 2005.

\begin{tabular}{|c|c|c|c|c|c|c|}
\hline \multirow{2}{*}{ Parameter } & \multicolumn{2}{|c|}{ May } & \multicolumn{2}{c|}{ October } & \multicolumn{2}{c|}{ July } \\
\cline { 2 - 7 } & range & mean & range & mean & range & mean \\
\hline Acidity $(\mathrm{pH})$ & $7.56-8.24$ & 8.04 & $7.22-8.89$ & 8.00 & $7.41-7.57$ & 7.50 \\
\hline Phosphate $(\mu \mathrm{gA} / \mathrm{l})$ & $0.22-2.21$ & 1.16 & $0.09-19.85$ & 3.69 & $0.09-2.70$ & 0.58 \\
\hline Nitrate $(\mu \mathrm{g} A \mathrm{~A})$ & $0.14-1.37$ & 0.54 & $1.70-5.60$ & 2.61 & $0.13-1.51$ & 0.35 \\
\hline Silicate $(\mu \mathrm{gA} /)$ & $12.54-41.65$ & 27.02 & $4.80-97.81$ & 24.93 & $4.21-32.93$ & 10.61 \\
\hline
\end{tabular}

Table 2. Acidity $(\mathrm{pH})$ and nutrient concentrations in the estuary of Cisadane in May 2004, October 2004 and July 2005.

\begin{tabular}{|c|c|c|c|c|c|c|}
\hline \multirow{2}{*}{ Parameters } & \multicolumn{2}{|c|}{ May } & \multicolumn{2}{c|}{ October } & \multicolumn{2}{c|}{ July } \\
& range & mean & range & mean & range & mean \\
\cline { 2 - 7 } & $6.09-7.06$ & 6.98 & $6.72-7.22$ & 6.97 & $7.01-7.05$ & 7.03 \\
\hline Acidity $(\mathrm{pH})$ & $0.84-1.80$ & 1.32 & $19.25-31.24$ & 25.24 & $1.26-2.65$ & 1.96 \\
\hline Phosphate $(\mu \mathrm{gA} / \mathrm{l})$ & $3.60-4.14$ & 3.87 & $6.34-6.38$ & 6.36 & $9.80-10.01$ & 9.91 \\
\hline Nitrate $(\mu \mathrm{gA} /)$ & $89.08-100.84$ & 94.96 & $104.87-108.79$ & 106.83 & $383.51-383.51$ & 383.51 \\
\hline Silicate $(\mu \mathrm{gA} /)$ & & & & &
\end{tabular}

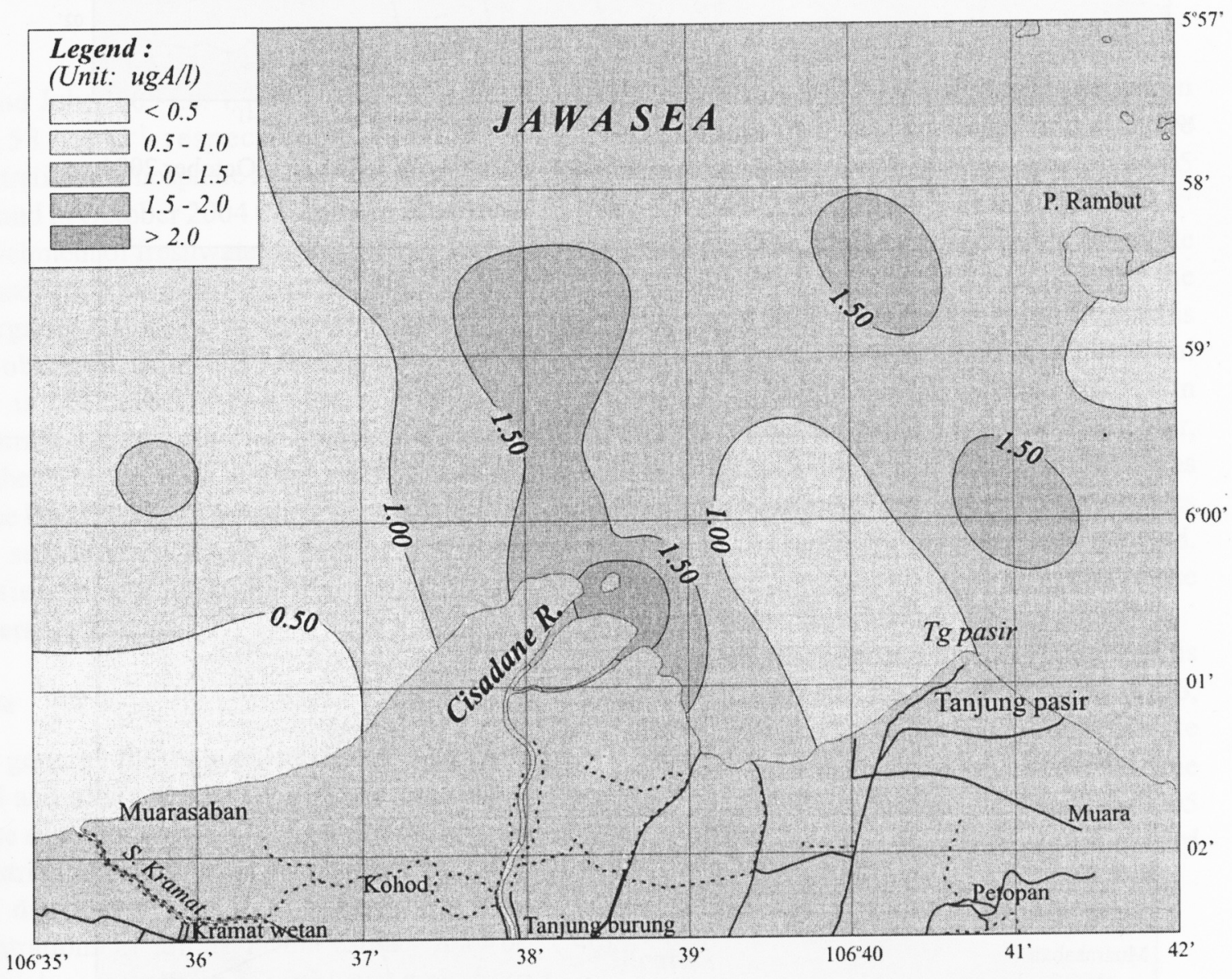

Figure 2. The distribution of phosphate concentration in the Cisadane Estuary, May 2004. 


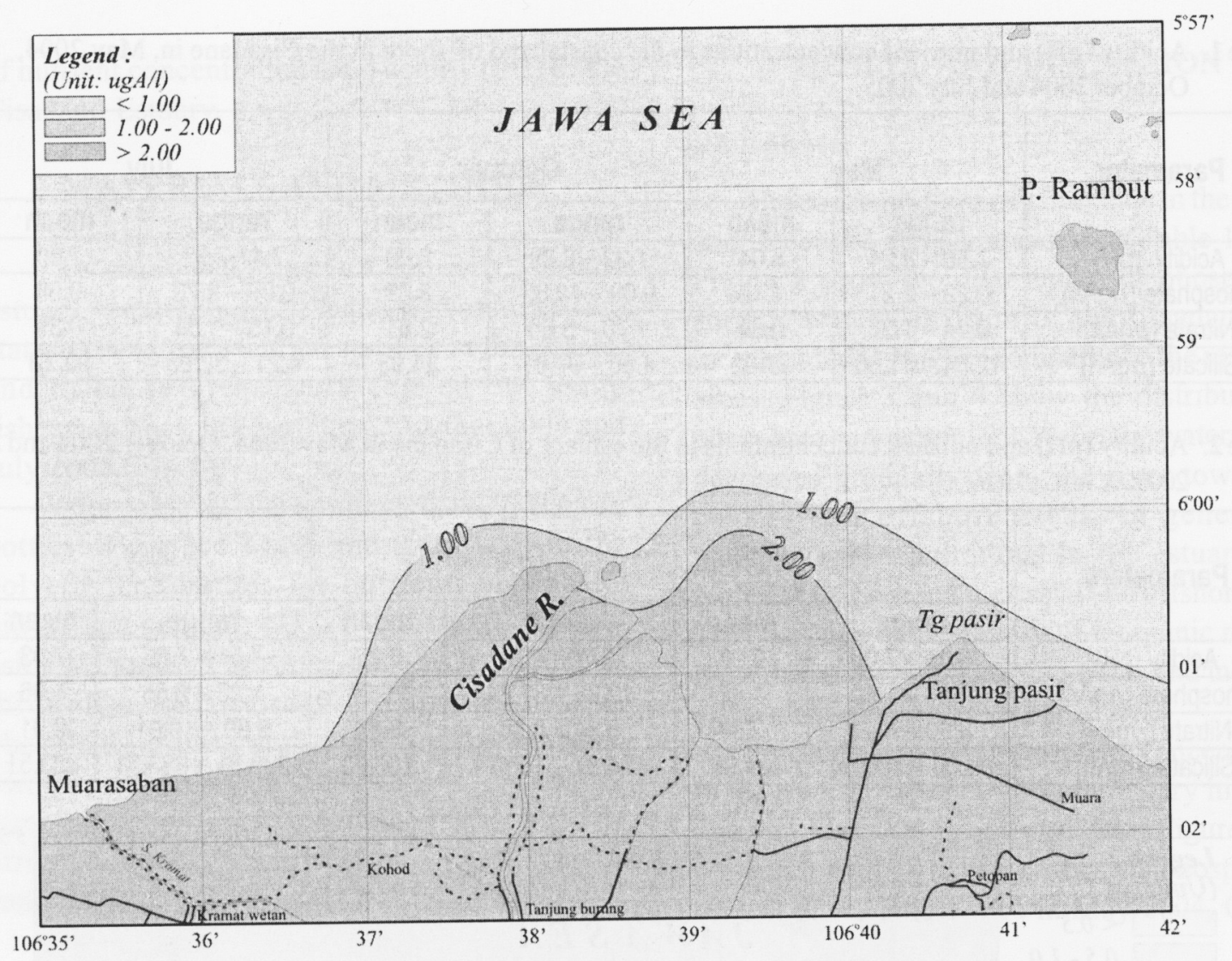

Figure 3. The distribution of phosphate concentration in the Cisadane Estuary, October 2004.

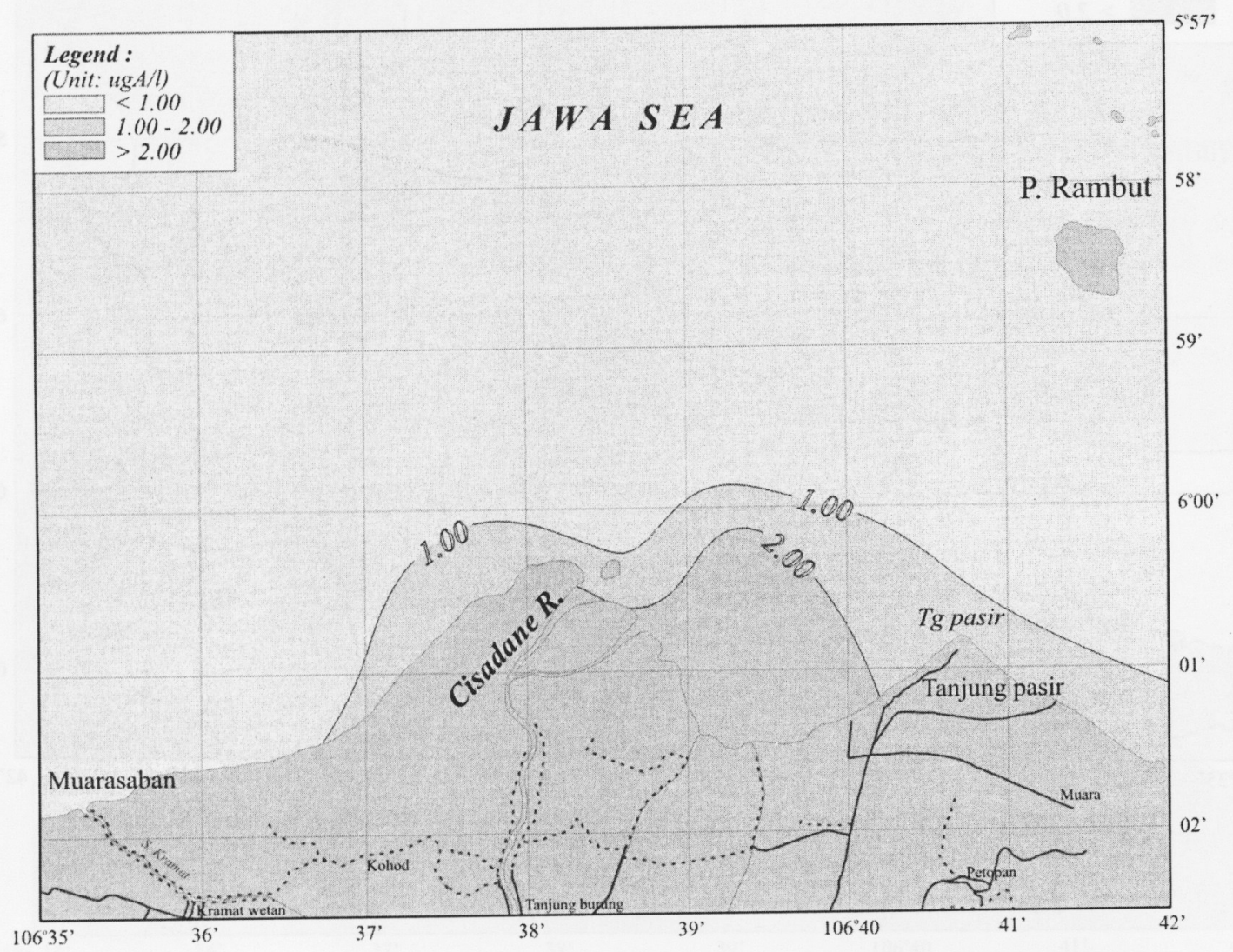

Figure 4. The distribution of phosphate concentration in the Cisadane Estuary, July 2005 


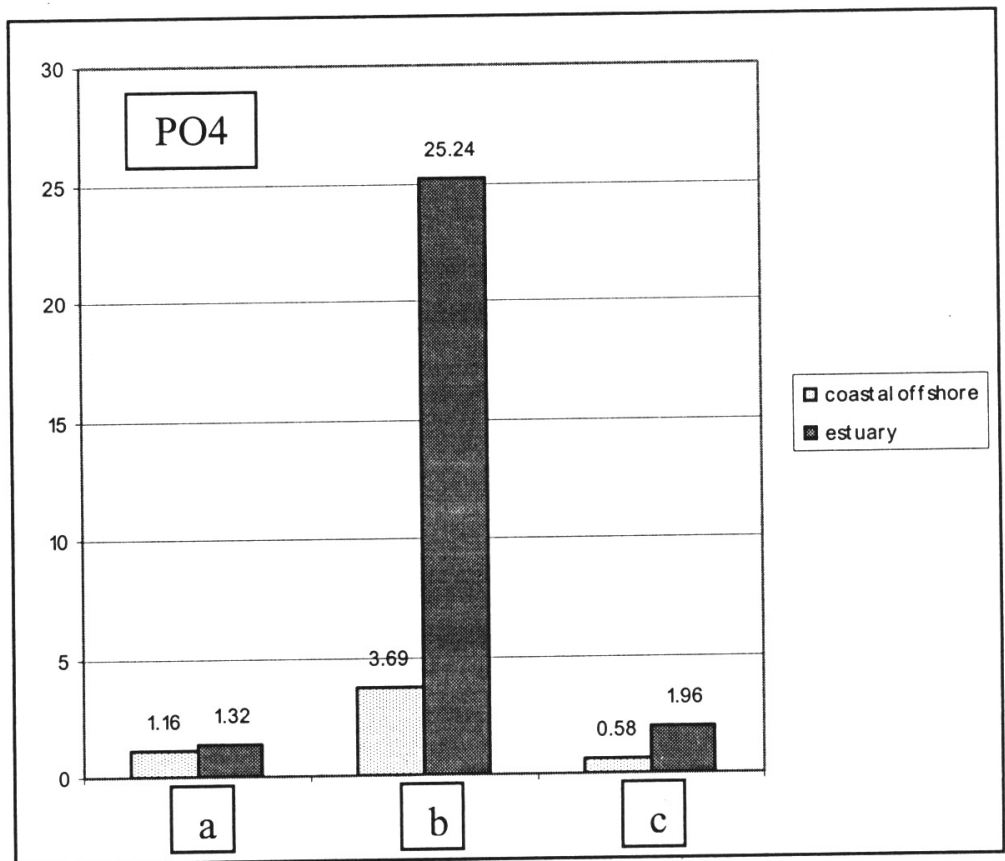

Figure 5. Phosphate concentration on May 2004(a), October 2004(b) and July 2005(c) in the Cisadane Estuary.

2004 and July 2005 i.e. $1.16 \mu \mathrm{gAl}^{-1}, 3.69 \mu \mathrm{gAl}^{-1}$ and $0.58 \mu \mathrm{gAl}^{-1}$ respectively. The higher concentration of phosphate at coastal and offshore also found in October 2004 this may be caused by the enrichment of freshwater from the land during this season (rainy season) which had high organic and iorganic material. In comparison with the result obtained from the Mamberamo waters which is $0.22 \mu \mathrm{gAl}^{-1}$ (Muchtar, 2000), the concentration of phosphate in the Cisadane areas are higher. This was due to the supply of material from the land produced by anthropogenic activities in the surrounding areas. There are no such activities in the surrounding areas of the Mamberamo Estuary.

\section{Nitrate}

In general the concentration of nitrate in coastal and offshore areas were lower compared to those of the estuary (Table 1 and 2 and Fig.9). The distribution of nitrate concentrations is similar to the distribution of phosphate. The higher concentrations of nitrate in the estuary may be due to high concentration of freshwater input from the rivers of Cisadane.

The concentrations of nitrate in the estuary in October 2004 and July 2005 were higher than those in May 2004. This was due to the supply of inorganic material and domestic waste from the land which was much higher. The mean concentrations of nitrate at coastal and offshore area in May 2004, October 2004 and July 2005 were $0.54,2.61 \mu \mathrm{gAl}^{-1}$ and $0.35 \mu_{\mathrm{gAl}}{ }^{-1}$ respectively. The higher concentration of nitrate in October 2004 this may be caused by the enrichment of freshwater from the land during this season (rainy season) which had high terrestrial material. Compared with the results obtained in Mamberamo waters of $0.51 \mu \mathrm{gAl}^{-1}$ (Muchtar, 2000), the concentration of nitrate in this areas were higher. Same as phosphate this higher values was due to the supply of material from the land. Anthropogenic activities are much higher than those surrounding the Mamberamo Waters

In general, the concentrations of nitrate in this area were still normal for the coastal area. Fig. 6, 7 and 8 show the distribution of nitrate concentrations at the surface waters in Cisadane Estuary on May 2004, October 2004 and July 2005 which was gradually gets lower and lower toward the coastal and offshore areas.

\section{Silicate}

Table 1 and 2 show that the concentrations of silicate in the estuary of Cisadane in May 2004, October 2004 and July 2005 were higher than those in coastal and offshore areas. This was due to the supply of suspended material from the land. The 


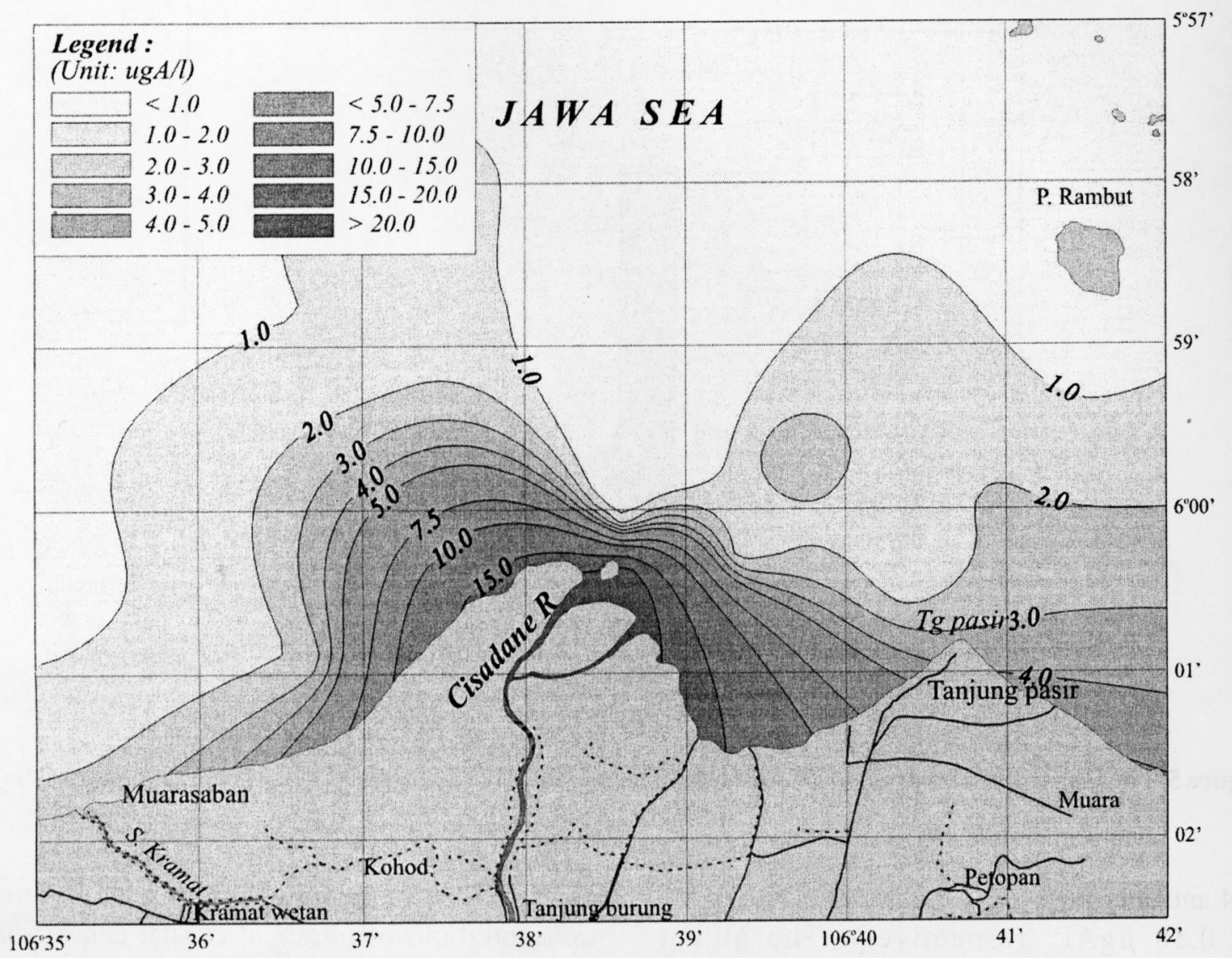

Figure 6. The distribution of nitrate concentration in the Cisadane Estuary, May 2004.

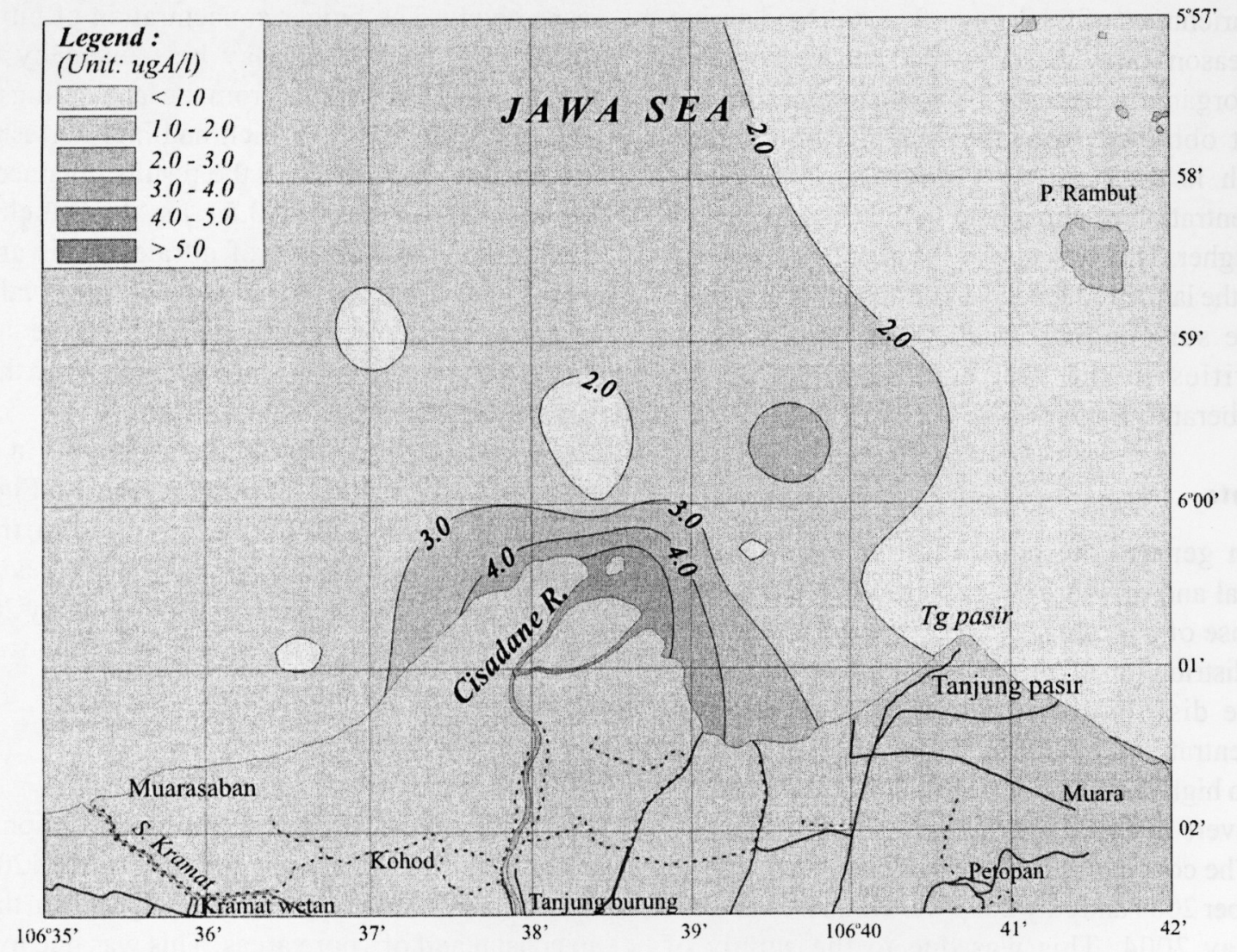

Figure 7. The distribution of nitrate concentration in the Cisadane Estuary, October 2004. 


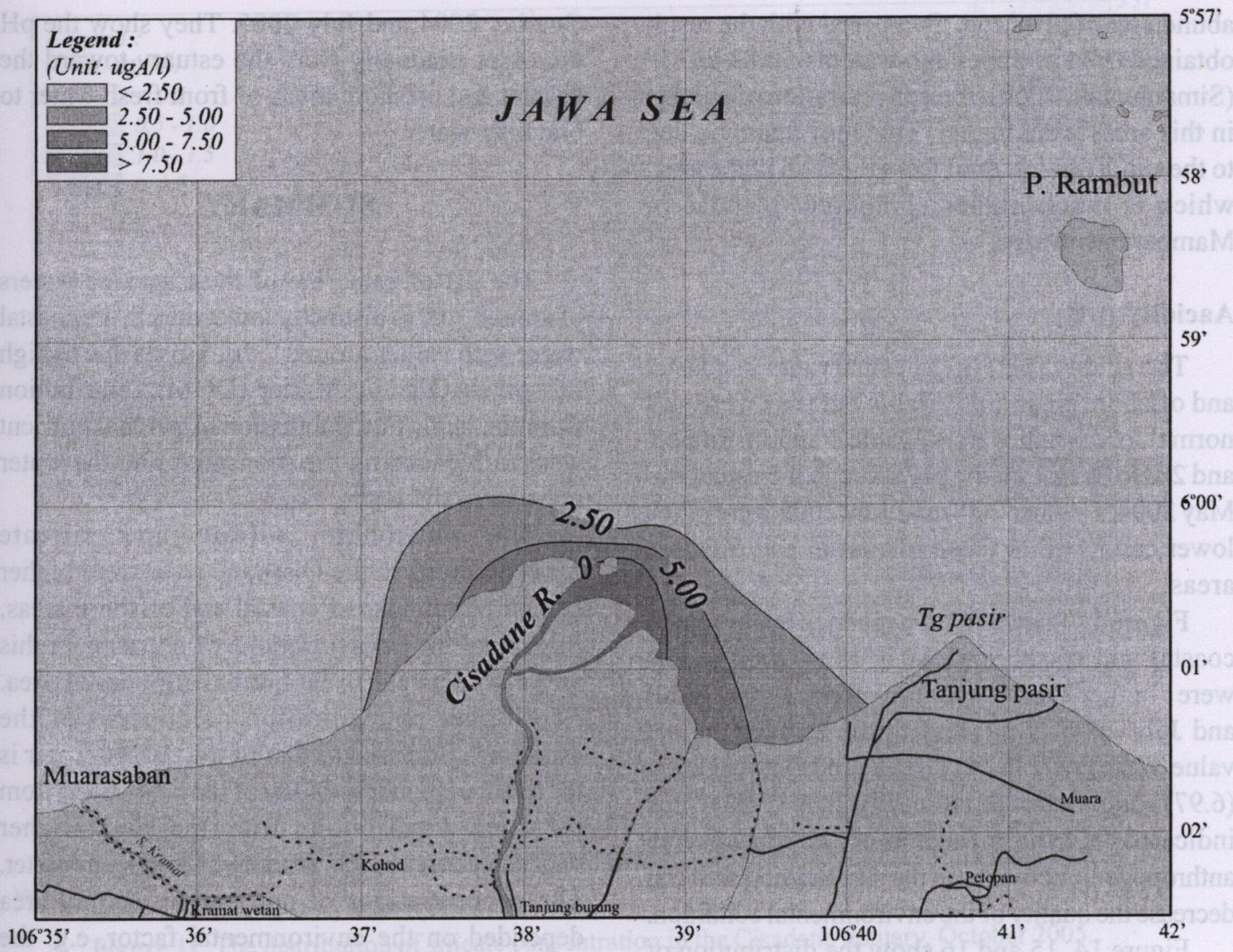

Figure 8. The distribution of nitrate concentration in the Cisadane Estuary, July 2005.

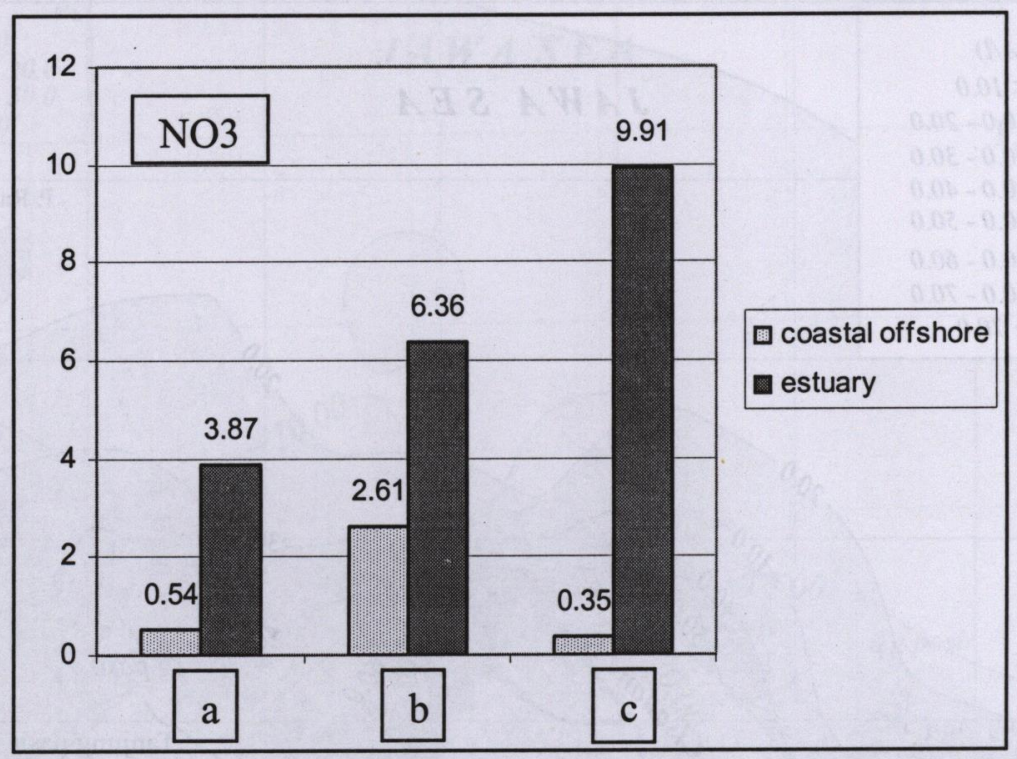

Figure 9. Nitrate concentration on May 2004(a), October 2004(b) and July 2005(c) in the Cisadane Estuary.

mean concentrations of silicate at coastal and offshore area in May, October and July were 27.02 $\mu \mathrm{gAl}^{-1}, 24.93 \mu \mathrm{gAl}^{-1}$ and $10.61 \mu \mathrm{gAl}^{-1}$ respectively and in the estuary of Cisadane were $94.96 \mu \mathrm{gAl}^{-1}$,
106.83 $\mu \mathrm{gAl}^{-1}$ and $383.81 \mu \mathrm{gAl}^{-1}$ respectively (Fig. 13). The variability of the silicate concentrations in this area were due to the effect of water mass from the land. Another explanation might be the 
abundance of plankton. Compared with the result obtained from Mamberamo waters of $0.83 \mu \mathrm{gAl}^{-1}$ (Simanjuntak, 2000), the concentration of silicate in this areas were higher. This may again be due to the supply of material from the land in the area, which is much higher compared to those in Mamberamo waters

\section{Aacidity (pH)}

The acidity $(\mathrm{pH})$ in the estuary and in coastal and offshore areas are variable but they were still normal for coastal waters (Table 1 and 2). Table 1 and 2 also show that the $\mathrm{pH}$ value in the estuary in May 2004, October 2004 and July 2005 were much lower compared to those in coastal and offshore areas.

Figure 17 in general, the mean $\mathrm{pH}$ value at the coastal and offshore areas in May 2004 (8.04) were higher than those in October 2004 (8.00) and July 2005 (7.50) and in the estuary the $\mathrm{pH}$ value were lower in May (6.98) and October 2004 (6.97) compared to those in July 2005 (7.03). This indicated that the influence of the land due to anthropogenic activities in the surrounding area can decrease the quality of the environmental condition.

Figure 14,15 and 16 show the distribution of $\mathrm{pH}$ value of Cisadane Estuary in May 2004,
October 2004 and July 2005 . They show the $\mathrm{pH}$ increases gradually from the estuary toward the coastal and offshore areas or from fresh water to brackish water.

\section{SUMMARY}

The $\mathrm{pH}$ of estuarine of the Cisadane waters of around 7.00 is distinctly lower than in the coastal water with values around 7.70 . This is due to high Dissolved Organic Matter (DOM) contribution from the land. The fluctuation of $\mathrm{pH}$ and nutrient were influenced by the monsoons and the water mass from the land.

The phosphate, nitrate and silicate concentrations in the Cisadane river were higher compared to those of coastal and offshore areas. In general the concentrations of nutrients in this area may be said to be normal for coastal area. The higher concentration of nutrient of the estuarine compared to that of the coastal water is the result of higher turbidity of the latter, apart from the direct contribution from the land. Higher turbidity causes higher reading of the spectrometer. The concentrations of nutrients in certain area depended on the environmental factor, e.g. the river input to the estuary and the decomposition of mangrove leaves in the area.

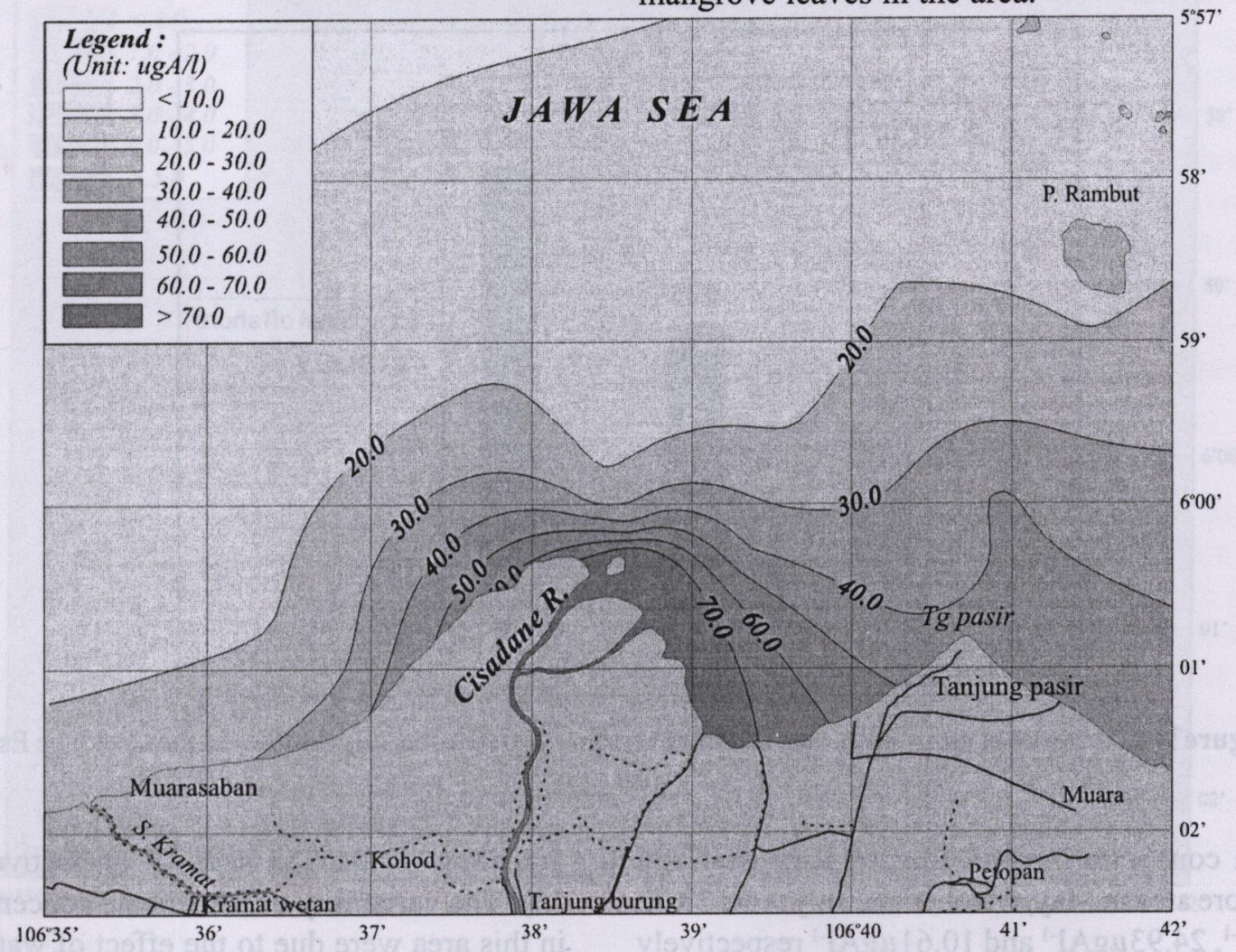

Figure 10. The distribution of silicate concentration in the Cisadane Estuary, May 2005. 


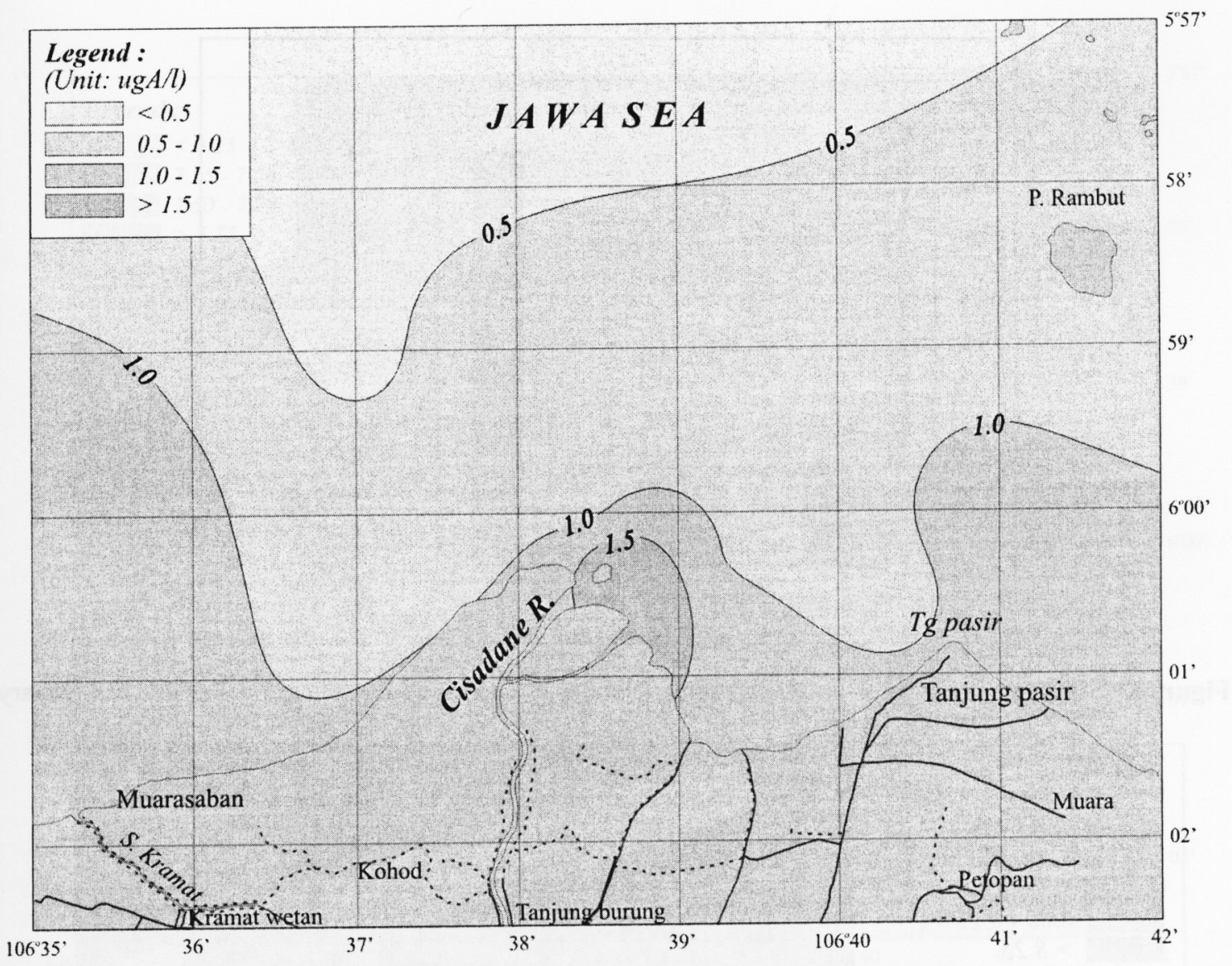

Figure 11. The distribution of silicate concentration in the Cisadane Estuary, October 2005.

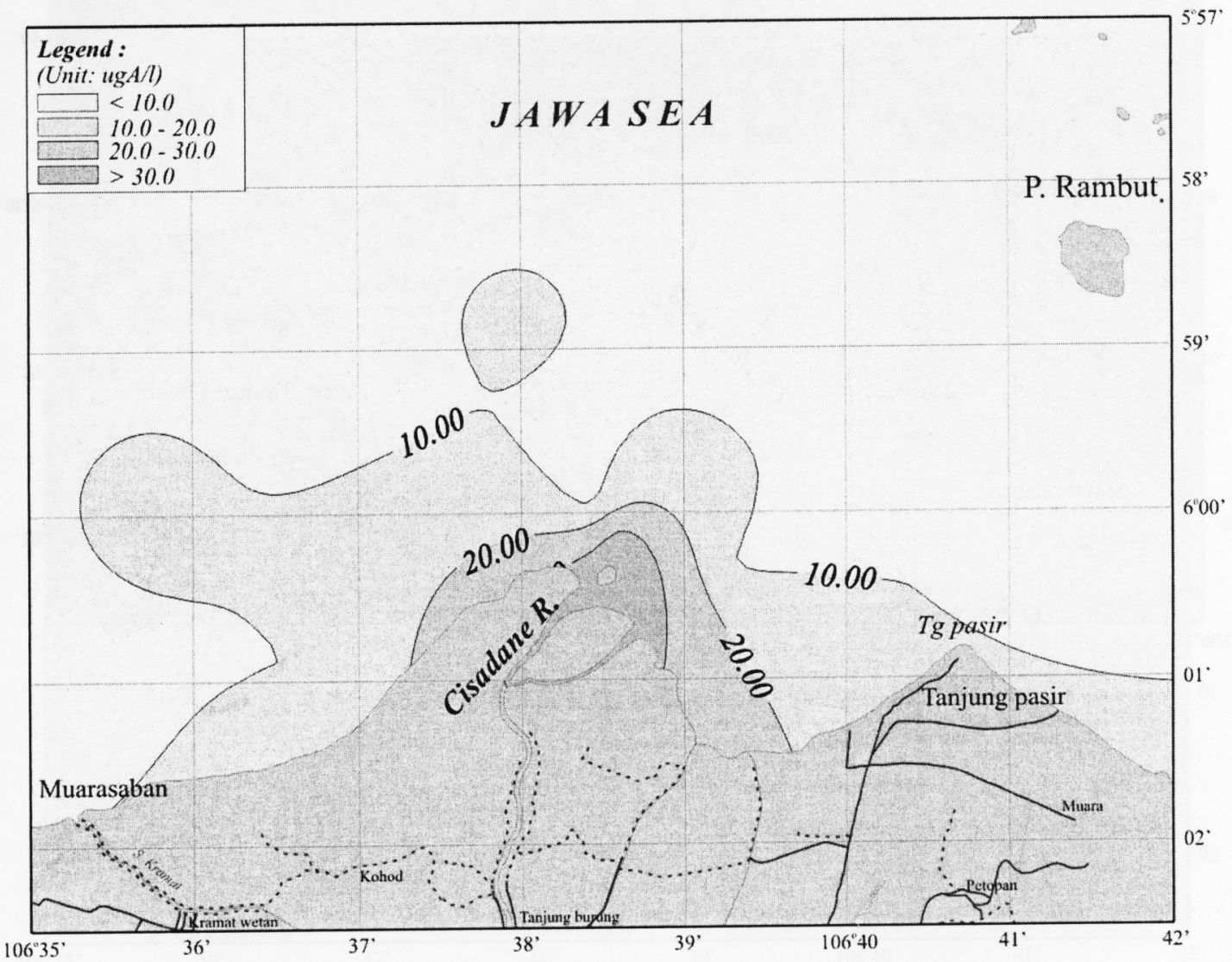

Figure 12. The distribution of silicate concentration in the Cisadane Estuary, July 2005. 


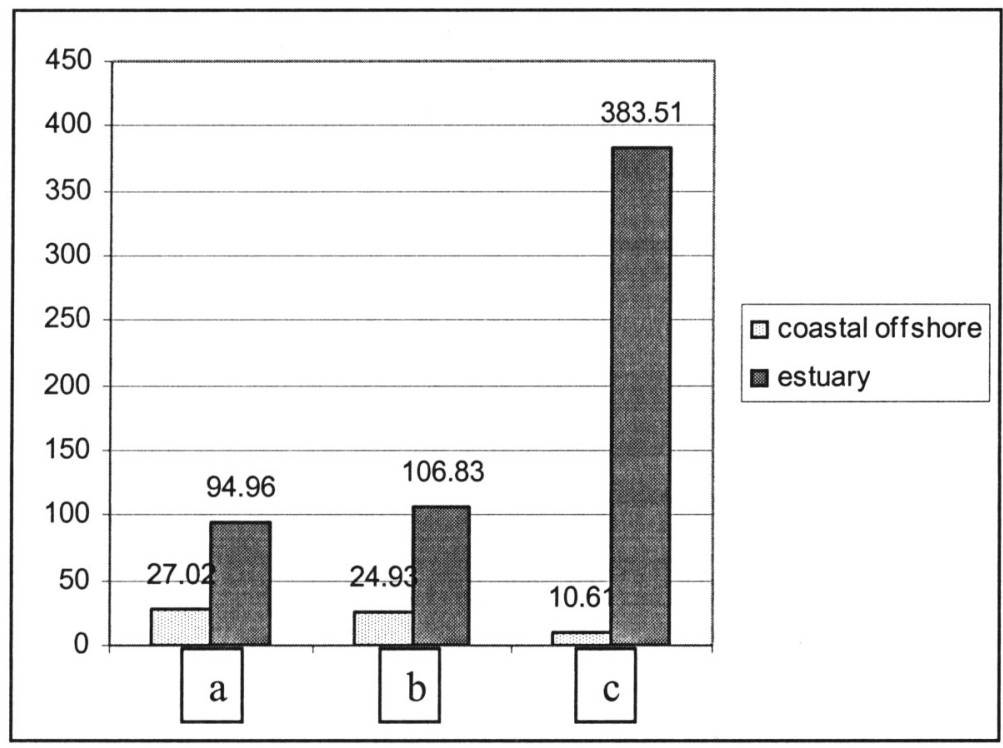

Figure 13. Silicate concentration on May 2004(a), October 2004(b) and July 2005(c) in the Cisadane Estuary.

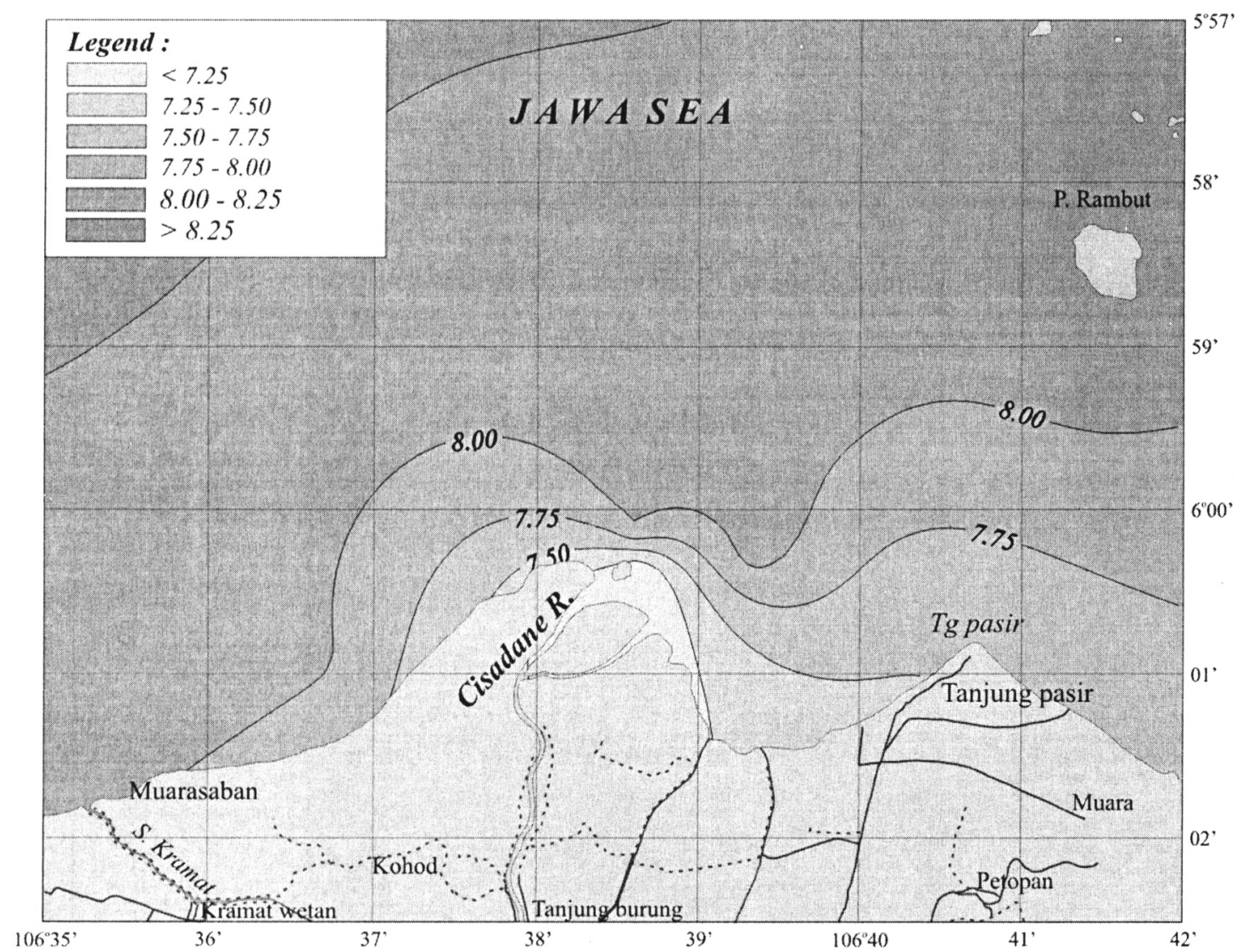

Figure 14. The distribution of acidity (pH) in the Cisadane Estuary, May 2004. 


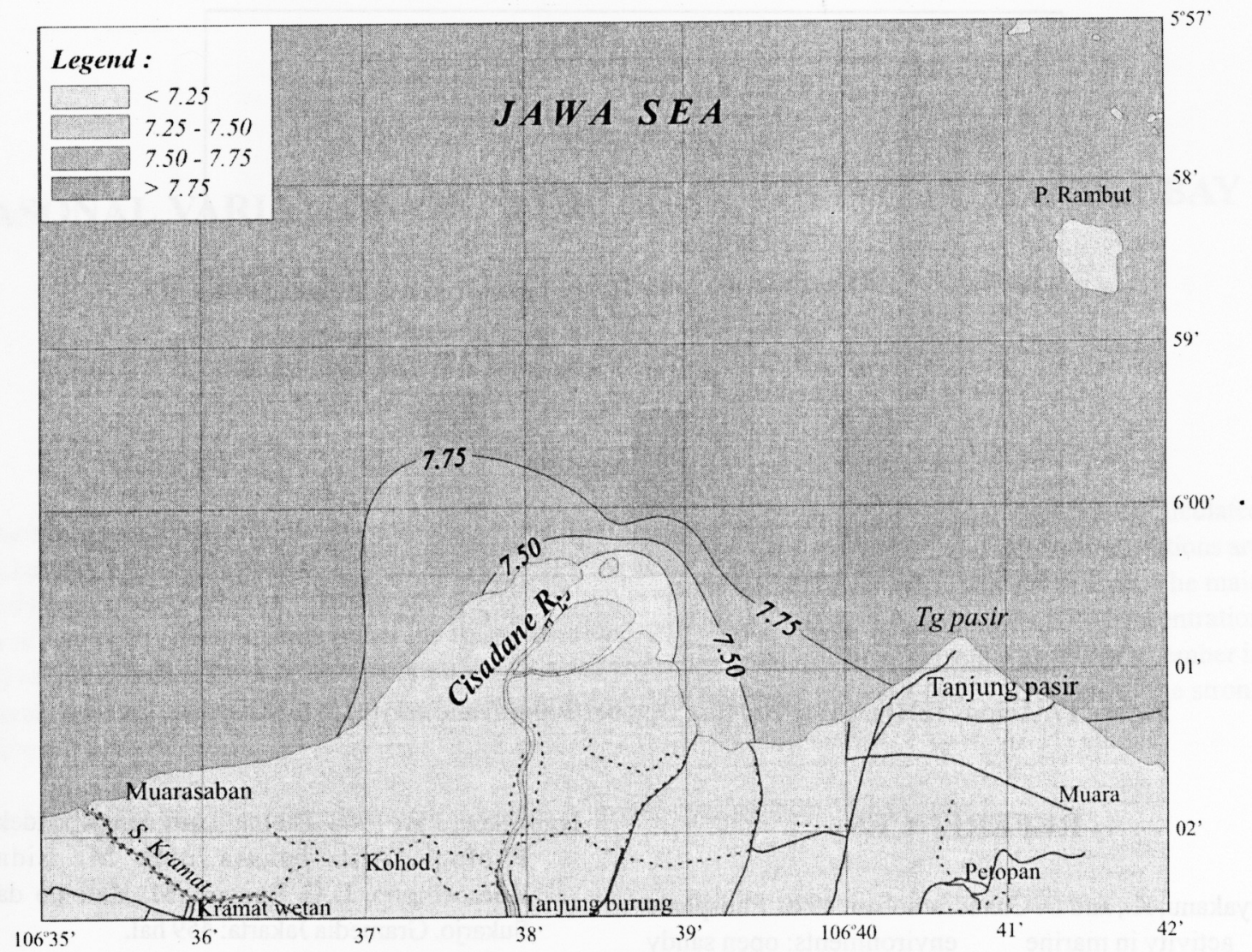

Figure 15. The distribution of acidity $(\mathrm{pH})$ in the Cisadane Estuary, October 2004.

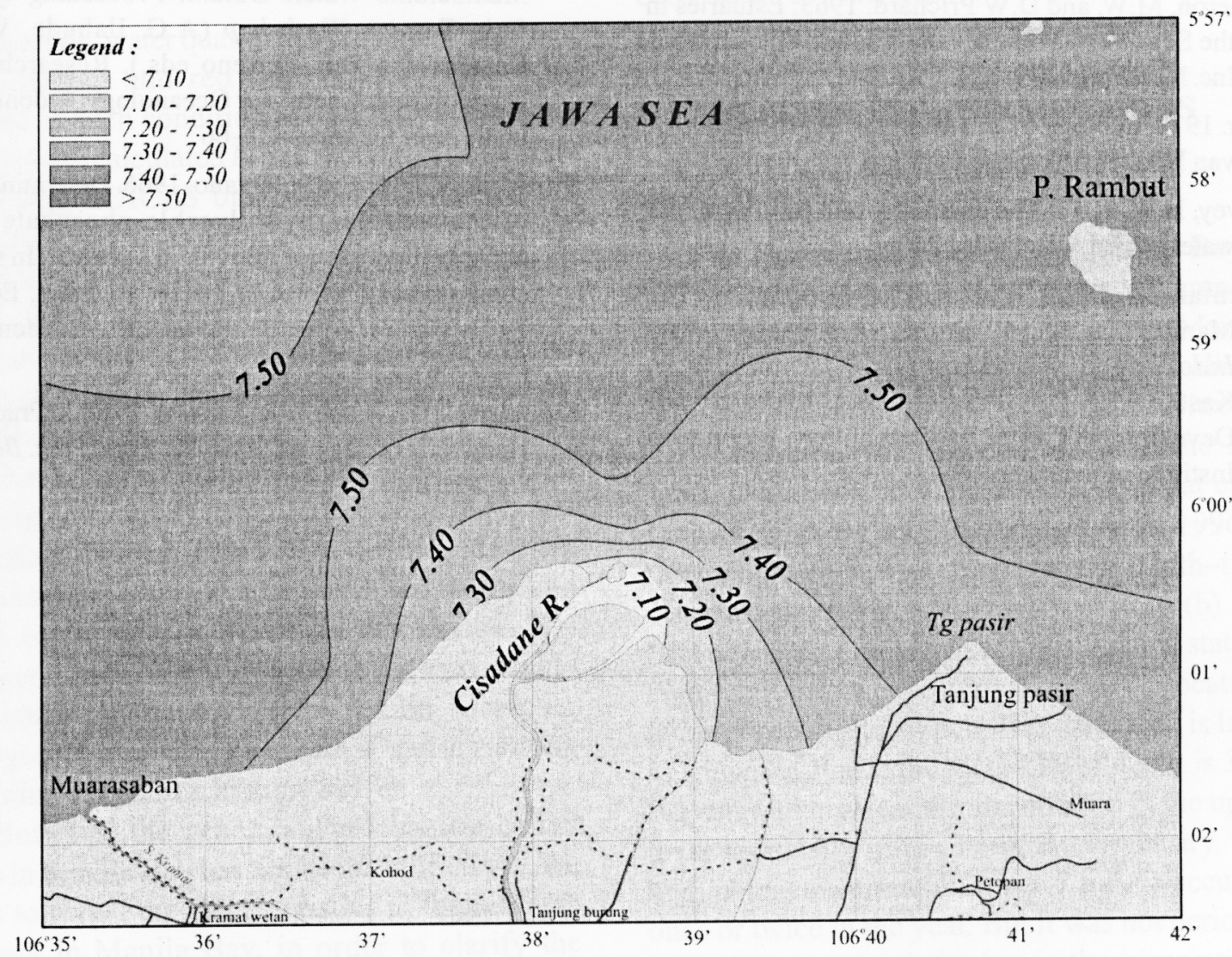

Figure 16. The distributions of acidity (pH) in the Cisadane Estuary, July 2005. 


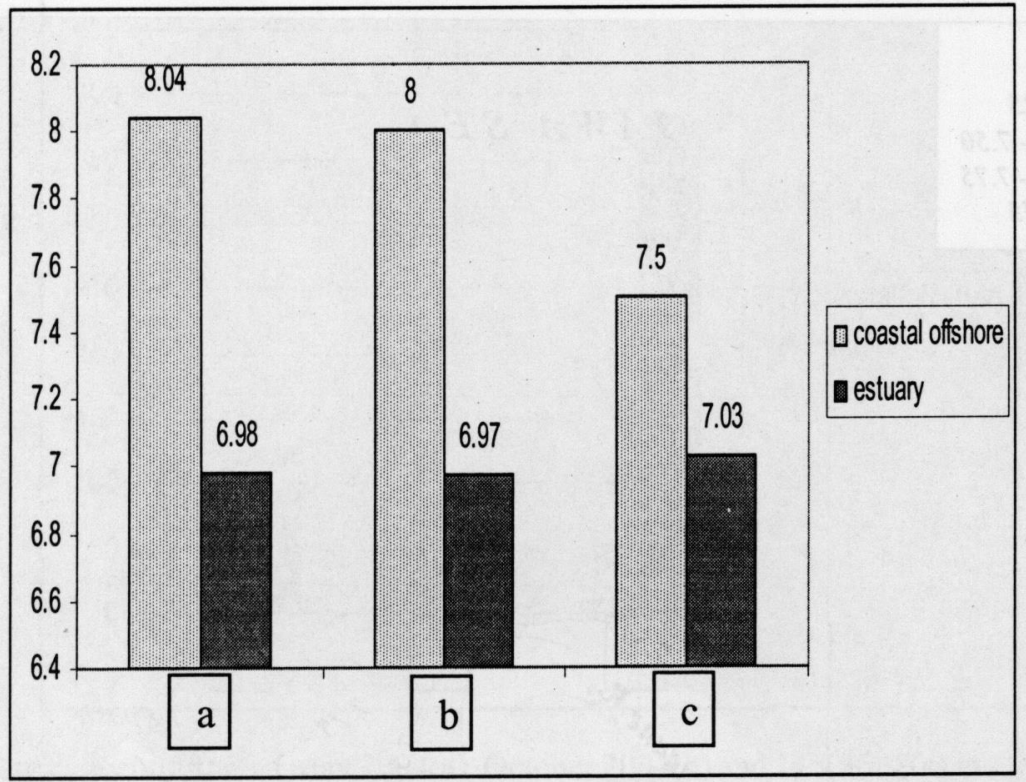

Figure 17. Acidity (pH) on May 2004(a), October 2004(b) and July(c) in the Cisadane Estuary.

\section{REFERENCES}

Ayyakanu, K., and D. Chandramohan. 1970. Phosphate activity in marine environments: open sandy beach at Porto Novo. Indian J. Biol. 8: 349-350.

Cameron, M.W. and D.W Prichard. 1963. Estuaries in the Sea (M.N. Hill ed.) vol II John Wiley \& Sons Inc. New York: 306-323.

Dyer. 1973. Ecology of Inland Water and Estuaries. D. van Nostrand Company: 485pp.

Harvey, H.W. 1957. The chemistry and fertility of sea water $2^{\text {nd }}$. Ed. Cambridge 240p.

Muchtar, M. 2000. Chemical Properties in The Mamberamo Waters Dalam: Proceeding of the Indo-Tropics Workshop (A.G. Ilahude, W.W. Kastoro dan D.P. Praseno eds.). Research and Development Centre for Oceanology, Indonesian Institute of Sciences: 49-60.
Nybakken, J.W. 1988. Biologi Laut, Suatu pendekatan Ekologi, Alih bahasa oleh M. Eidman, Koesoebiono, D.G. Bengen, M. Hutomo dan S. Sukarjo. Gramedia Jakarta: 459 hal.

Simanjuntak, M. 2000. Chemical Properties in The Mamberamo Waters Dalam: Proceeding of the Indo-Tropics Workshop (A.G. Ilahude, W.W. Kastoro dan D.P. Praseno eds.). Research and Development Centre for Oceanology, Indonesian Institute of Sciences: 61-66.

Strickland, J. D. H and Solorzano. 1966. Determination of monesterase hydrolysable phosphate and phosphomonesterase activity in seawater. In some contemporary studies in marine sciences. Edited by H. Barnes. Allen \& Unwin Ltd., London, pp. 665-674.

Strickland, J. D. H and T. R. Parsons. 1968. A Practical Handbook of Seawater analysis. Fish. Resh. Board. Canada. Bull. 167: 311. 